Article

\title{
Not All Demands Are Exhausted for Healthcare Workers. A Cross-Lagged Study on the Buffering Effect of Leadership Resources
}

\author{
Łukasz Baka, Dawid Ścigała *D and Krzysztof Grala
}

check for updates

Citation: Baka, Ł.; Ścigała, D.; Grala, K. Not All Demands Are Exhausted for Healthcare Workers.

A Cross-Lagged Study on the Buffering Effect of Leadership Resources. Sustainability 2021, 13, 10623. https://doi.org/10.3390/ su131910623

Academic Editors: Adnan Ul Haque, Erhan Aydin, Vipin Nadda and Basharat Javed

Received: 30 July 2021

Accepted: 14 September 2021

Published: 24 September 2021

Publisher's Note: MDPI stays neutral with regard to jurisdictional claims in published maps and institutional affiliations.

Copyright: (c) 2021 by the authors. Licensee MDPI, Basel, Switzerland. This article is an open access article distributed under the terms and conditions of the Creative Commons Attribution (CC BY) license (https:/ / creativecommons.org/licenses/by/ $4.0 /)$.
Institute of Psychology, The Maria Grzegorzewska University, 02-353 Warsaw, Poland; lbaka@aps.edu.pl (Ł.B.); kgSD6@aps.edu.pl (K.G.)

* Correspondence: dscigala@aps.edu.pl

\begin{abstract}
This study investigated the cross-lagged effects of a three job demands on exhaustion and buffering function of leadership resources among Polish healthcare workers. Job demands include quantitative and two emotional (related to engaging in the patient's personal problems and related to hiding emotions) demands, while leadership resources include quality of leadership and trust in management. The study was conducted in two waves (both of them in COVID-19 pandemic), with a one-year interval between the measurements. Data were collected among 1251 healthcare workers. A moderated regression analysis showed that quantitative demands and demands for hiding emotions (T1 but not emotionally engagement in the patient's personal problems) were related to high exhaustion (T2). Both leadership resources (T1) diminished the negative impact of quantitative (not emotional) demands on exhaustion, but the buffering effect of trust was stronger. Furthermore, the two leadership resources interact with each other and together neutralize the effects of quantitative demands. Specifically, the lowest level of exhaustion was observed in those healthcare workers who had high levels of both resources, measured one year before. The implications for theory and research on the effects of different job demands on exhaustion in pandemic are discussed.
\end{abstract}

Keywords: job demands; leadership resources; occupational stress

\section{Introduction}

The COVID-19 pandemic has significantly changed the healthcare workers" "world of work". It confronted them with new, previously unknown challenges, such as staff shortages, insufficient equipment, inadequate protection from contamination, risk of infection, overload, social stigmatization, isolation as well as lack of contact with their families [1,2]. Dealing with these job-related factors on a daily basis gradually depletes the personal and job resources of healthcare workers [3] and makes occupational specific demands (e.g., quantitative and emotional demands) become more burdensome [4,5]. In other words, under the stressful conditions, performing daily professional duties, entering into close relations with infected patients, following their expectations and emotional control during contact with them mobilize more coping resources than usual [6]. Both quantitative and emotional demands are a source of daily strain for medical staff [7-9] which over time results in exhaustion, perceived as the core of job burnout [10]. Exhaustion is a response to intensive physical, affective and cognitive strain; it manifests in fatigue, weariness and a decrease in energy [10]. Exhaustion may deteriorate health professionals' performance of tasks, leading to medical errors in the battle against COVID-19 [11]. It also affects the health of patients. Several systematic reviews of the literature have found that high levels of job burnout in health care professionals are associated with less-safe patient care [12,13]. The results of several meta-analyzes of studies indicate the competencies of managerial staff as a key job resource that help health-care workers minimize the negative effects of prolonged high job demands [14-17]. In the current study, we try to answer two main 
questions: Do quantitative and emotional demands lead (in long run) to exhaustion of health-care workers in pandemic time? Do leadership resources (including quality of leadership and trust management) buffer the hazardous effect of quantitative and emotional demands on exhaustion?

Most studies on job demands-exhaustion relation were carried out in Western (not Eastern) European countries, where the health-care workers are better paid and their working conditions seem to be more comfortable [18-20]. A certain limitation of these studies is their cross-sectional nature. A point is currently being raised that on the basis of a single measurement of variables at one time point, it is not possible to determine unequivocally the existence of a mediation effect [21]. In the current research, job demands-exhaustion link and moderation effect of leadership are tested in a one-year cross-lagged design in Poland, where working conditions among medical staff are highly demanding $[18,19,22]$. For example, according to the report Health at a Glance Europe 2020 prepared by the OECD, Poland has one of the lowest numbers of employed nurses, doctors and dentists per 1000 inhabitants in Europe-5.1 for nurses (compared to an average of 8.2 for EU), 2.4 for doctors (average of 3.8 for EU) and 0.4 for dentists (average of 0.8 for EU). The Polish Main Chamber of Nurses and Midwives [23] forecast that by 2030 this ratio will have dropped to 3.81 for nurses.

To our knowledge, there are no studies on a longitudinal effect of quantitative and emotional demands on exhaustion among front-line health-care workers conducted during the COVID-19 pandemic. As found in recent studies pandemic is expected to have a substantial psychological impact particularly on health-care providers $[8,24]$. They comprise a notable proportion of the people who contracted the illness. For example, the International Council Of Nurses (ICN) [25] estimates (as of 31 December 2020) that on average around $10 \%$ of all confirmed COVID-19 infections are among healthcare workers. The World Health Organization (WHO) [26] confirmed (as of 24 May 2021) that at least 115,000 health workers have died due to pandemic. According to 21 June 2021 data (provided by database Statista [27]), coronavirus in Poland has infected: 72,410 nurses, 29,433 doctors, 11,094 physiotherapists and 7207 midwives. Deaths due to coronavirus were: 231 doctors, 185 nurses, 22 midwives and 19 pharmacists. This high rate of infection and mortality has a tremendous impact on health-care workers well-being. Additional issues such as shortage staff, shortage of personal protection equipment supplies, poor working conditions as well as lack of consistent information about the spread of the virus, its contagiousness, the effectiveness and prevention can aggravate this situation. Some findings indicate that different types of job demand interaction with each other and exacerbate the harmful effect [4], therefore it can be assumed that the detrimental functions of quantitative and emotional demands will be particularly strong in a situation of crisis, uncertainty and work overload, that pandemic.

\subsection{The Effects of Quantitative and Emotional Demands on Exhaustion among Healthcare Workers}

The classic occupational stress concepts, e.g., job demand-control model (JD-C; [28]), focused mainly on quantitative demands that were measured by the number of hours spent on work (workload), the amount of work performed (work intensity), the amount of activities performed per unit of time (time pressure) and the subjectively assessed physical and mental effort put into work [29]. They are associated with the physical and psychological costs incurred by the worker during carrying out tasks. Several meta-analysis studies confirmed that quantitative demands have negative impact on exhaustion [30-33], also in group of healthcare workers [34-36]. The averaged correlation coefficient in the cited studies ranged from $\rho=0.25$ to $\rho=0.65$. The emphasis on quantitative demands mainly stems from the industrial work environment analysis that the JD-C model was built on.

Along with the increase in the number of service work on labor market [37], more and more attention was paid to these types of work that require close emotional relationships with other people and active involvement in their problems [38]. Currently, about 
$70 \%$ of the work force consist service workers [39], therefore emotional demands poses risks to workers as a result of the interpersonal nature underpinning this line of work. Emotional demands are defined as "those aspects of the job that require sustained emotional effort" [40]. In the group of health care workers, emotional demands usually cover two kinds of job conditions. The first of them is associated with emotionally burdensome relationships with other people (e.g., long-term care, interpersonal conflicts, supervision over aggressive patients) and the number and intensity of negative emotional experiences in the workplace (fear, anger, hostility, sadness). The consequence of negative emotions at work is job strain $[41,42]$ and in the longer term deterioration of mental and physical health [43-45]. The second type of emotional demands concerns the observance of the emotional display rules consisting in showing positive emotions and hiding the negative ones [46,47] during social interactions (e.g., with a co-worker, supervisor, patient), traumatic events (e.g., emergency, patient death) and daily routines (e.g., dressings change, medical treatment). Researchers argue that emotional regulation at work, similar to any other form of self-regulation, requires effort and thus reduces the employee's personal resources, which may result in worse health $[43,48]$.

Numerous evidence indicates that occupations largely relying on interpersonal interactions (e.g., with patients) are exposed to the highest levels of emotional demands [49]. Emotional demands in this context are thought to stem from exposure to patient suffering [40], patients' violence [50] or high demands and expectations from patients [51]. These experiences and requirements can negatively impact well-being of the healthcare workers. Some studies demonstrate that emotional demands are at least as important, or more important, than psychological-quantitative demands (e.g., workload) in terms of their impact on employee well-being in service work [9]. A large body of cross-sectional [52-54] and (more importantly) prospective studies [9,55-58] has shown that emotional job demands are related to a variety of poor health symptoms, particularly job burnout in different countries and different occupational groups. For example, a one-year cross-lagged study found an association between emotional demands (e.g., handling troublesome clients) and emotional exhaustion among Swedish social insurance [9] and Belgian technology sector employees [59]. Similar results were obtained by Lorente Prieto et al. [56] in an eight-month interval measurement study carried out in a group of Spain teachers. The study on Swedish healthcare workers, in turn, supported the negative impact of some occupational specific job demands (i.e., "pain and death", "patient and relative needs", "threats and violence", "professional worries") on job burnout measured one year later [57].

The negative impact of quantitative and emotional demands on exhaustion may be understood through the lens of the health erosion pathway of the job demands-resources model [60]. In accordance with the health erosion pathway, prolonging job demands results in the mobilization of employees' strength and effort put into work in order to maintain the required level of performance. This is associated, however, with high psycho-physiological costs-activation of the sympathetic nervous system, irritability and fatigue. A chronically high level of stressors gradually depletes the employee's resources required to cope with stress-e.g., time, energy, mental and physical strength, abilities, equipment and social support. This can be source of exhaustion. In fact, a meta-analysis of studies has shown that the strongest determinant of job burnout is the high level of chronic job demands $[30,32,33]$.

\subsection{Moderating Effect of Leadership}

According to JD-R model, leadership is perceived as an example of job resources [61], that may reduce job demands and the associated physiological and psychological cost, are functional in achieving work goals, and stimulate personal growth, learning and development [62]. From perspective of employees, "good" leadership usually concerns two groups of behaviors-related to achieving a goal and related to building group relationships and trust in the leader [63]. In classical leadership models, these behaviors were classified under different leadership styles and were also called slightly differently-e.g., autocratic and democratic leadership [64], consideration and initiating structure [65], employee-oriented 
and production-oriented [66], task-oriented and relationship-oriented [67], transactional and transformational leadership [68] - they related, however to the same "domains" of the leader's activities. For example, the consideration includes people-oriented behaviors and is based on a close relationship between a superior and a subordinate, which is marked by mutual trust, care for the employee and respect for ideas submitted by the employee. Initiating structure, in turn include roles, objectives, activities, planning and delegation. In contrast with the people-oriented style above, this is a task-oriented perspective that focuses on behaviors such as setting individual expectations, maintaining performance standards, planning tasks and ensuring the group maintains organizational expectations [69]. Both constructs are correlated with variety of organizational outcomes. A meta-analysis of more than 2000 respondents showed that consideration was more strongly related to leader satisfaction, job satisfaction, motivation and leader effectiveness, while initiating structure was slightly more strongly related to leader and group job performance [70].

Above distinction on task vs. relational-oriented behaviors in assessment of leader by group is in agreement with the general idea of social perception, which indicates two groups of information as particularly important in shaping of the global assessment of another person. The first of them refers to human efficiency, effectiveness and competence; the second relates to the moral categories and beliefs that the other person is trustworthy [71,72]. More recent leadership models have developed this basic typology of leadership behaviors. For example, Yukle's Hierarchical Taxonomy of Leadership Behaviors [73], postulate four leadership orientation: task, relationships, change and external behaviors (e.g., representing). Behrendt, Matz and Göritz [74], within the integrative model, distinct three task-oriented behavior categories (enhancing understanding, strengthening motivation and facilitating implementation) and three relation-oriented behavior categories (fostering coordination, promoting cooperation and activating resources).

The beneficial role of leadership was investigated mainly in the context of employees' job performance [75-78], however, several meta-analytical reviews indicate that leadership may be also an important determinant of work-related health outcomes in organizations [14-17]. For example, a review containing 49 papers, published between 1980 and 2010 found support for leader stress and affective well-being being associated with employee stress and affective well-being [17]. It could be argued that stress involves a crossover contagion process [79], where leaders' mood is seen as being "contagious". Montano et al. [16], in turn used a meta-analytic models to estimate the association between variety of leadership styles and six categories of mental health-related outcomes, such as affective symptoms, burnout, stress, low well-being, low psychological functioning and health complaints. Both task-oriented and relational-oriented leadership are related to low ratio of all six health-related outcomes, however averaged correlation coefficients were higher for the relationship-oriented style than for the task-oriented ones $(\rho=0.40$ and $\rho=0.20$ for job burnout, respectively). Other meta-analysis including data from 21 high quality studies on healthcare workers showed that perceptions of a good organizational climate (including "good" leadership) were significantly associated with positive employee mental health outcomes such as lower levels of burnout, depression and anxiety [14].

Leader behaviors such as support, empowerment and a high-quality relationship between leaders and their employees might prevent both stress and improve employees' stress coping and affective well-being [17] as well as innovative work behavior [80,81] and team performance $[82,83]$, also in pandemic period. Only a few studies tested moderational function of leadership in job demands-burnout link. Their findings are inconsistent and depend on the types of job demands and types of leadership that were taken into consideration [84-87]. For example, a study on Taiwanese nurses found that perceived leadership effectiveness reduced the effect of workload on job burnout [84]. Similarly, Lee et al. [85] supported buffering role of leader-member exchange (LMX; perceived the relationship with their supervisor positively) in the workload-job burnout relations. The results obtained in other study are slightly complex, however. Based on challenge-hindrance model of stress [88], Chinese authors observed, for example that while leadership buffers the relation 
between challenge stressors and emotional exhaustion, it enhances the relation between hindrance stressors and emotional exhaustion [86]. Other studies show that the direction of moderation may also be influenced by the type of leadership. While transactional leaders reduce the negative effect of hindrance stressors on job performance, transformational leaders enhance the positive effect of challenge stressors on job performance [87]. Conversely, two other studies have found support for the buffering role of transformational leadership in workload-burnout relations [89,90].

\subsection{The Aim of Study}

The aim of the study is to investigate (1) a one-year cross-lagged effect of quantitative and emotional demands (related to demands for close relationship with patients and demands for hiding emotions) on exhaustion and (2) moderation effect of leadership on the quantitative/emotional demands-exhaustion link in the group of front-line healthcare workers. Two types of leadership behaviors (moderators), assessed from the perspective of subordinates, were taken into account: (1) task-oriented, including initiation of task, implementation, teamwork planning, management, conflict resolution and control skills (the so-called quality of leadership) and (2) relational-oriented, including caring for employees, sharing information and enabling you to openly express your views and feelings about work (the so-called supervisor trust). These two types of leadership behavior seem to be especially important in a condition of threat, crisis or uncertainty, such as the COVID-19 pandemic. Both the organizing and supervising work teams as well as building of social relations and trust at workplace may be helpful in dealing with quantitative and emotional demands experienced by medical workers [91,92]. Based on the theoretical premises presented in the two previous paragraphs and the results of cited studies, we have formulated two general research hypotheses:

Hypothesis 1 (H1). High job demands (T1, including quantitative and emotional demands) are related to high exhaustion (T2) of health-care workers.

Hypothesis 2 (H2). Leadership resources (T1, including quality of leadership and trust management) buffer the negative impact of job demands (T1) on exhaustion (T2) of health-care workers.

The proposed theoretical model is presented in Figure 1.

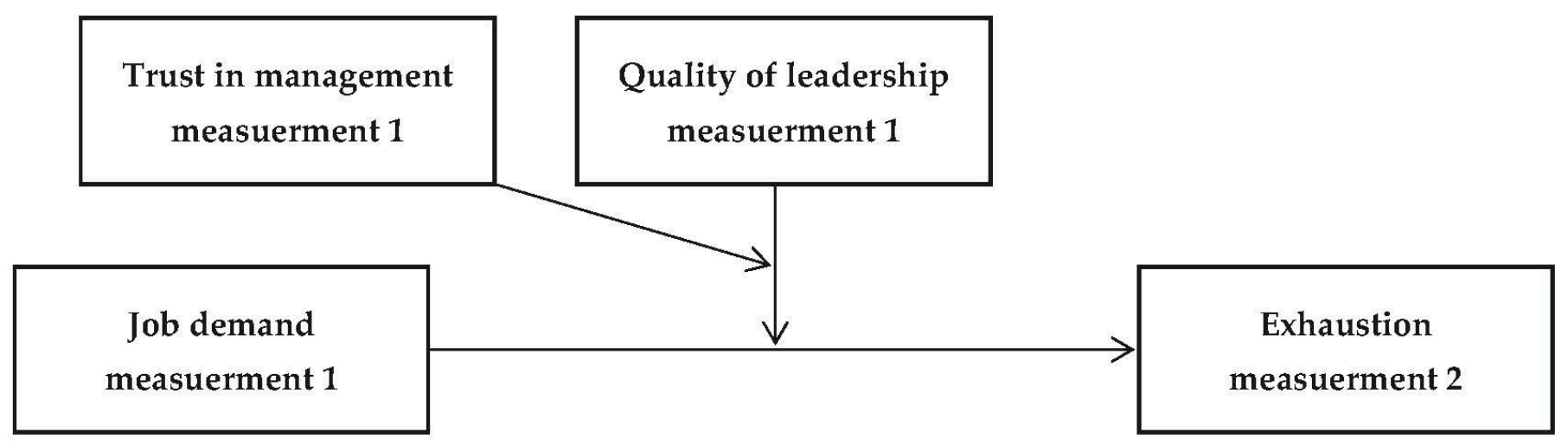

Figure 1. Theoretical model.

2. Materials and Methods

2.1. Participants and Procedure

The sample study $(n=1251)$ includes Polish front-line health-care workers, employed as nurses, midwives, paramedics, doctors, hospital wards, physiotherapists and medical support staff. The study was conducted in two waves, with a one-year interval between the measurements, at the hospitals and medical clinics, where the respondents were employed, 
by trained interviewers. First wave of study was carried out between February and April 2020, the second after 12 months. All participants were treated in accordance with the ethical guidelines of the Helsinki Declaration and received a hard copy of the questionnaires along with a letter explaining the purpose of the study. Full confidentiality of data and anonymity were secured. Participants were asked to fill out the questionnaires and seal them in envelopes, which were subsequently collected by research assistants. Out of 2000 distributed questionnaires, 1691 (85\%) were completed in the first step of the study (T1) and 1251 (63\% of the original pool) in the second stage (T2). Finally, 1251 subjects were included in the analysis. The analyzed group consisted of 914 women (73\%) and 337 men $(27 \%)$, between 20 and 70 years of age $(M=43.84, S D=10.51)$. Work experience ranged from 2 to 48 years $(M=18.48, S D=10.84)$.

\subsection{Measurement}

Job demands were measured with the COPSOQ II subscales [93] related to quantitative demands (e.g., How often do you not have time to complete all your work tasks?), emotional demands (e.g., Do you have to relate to other people's personal problems as part of your work?) and demands hiding emotions (e.g., Are you required to treat everyone equally, even if you do not feel like it?), in Polish version [94]. Each subscale contained four items, with possible answers from 1 (Always) to 5 (Never/Hardly ever). The reliability of the scales was, respectively, for quantitative demands T1 $\alpha=0.675 ; \mathrm{T} 2 \alpha=0.697$, emotional demands T1 $\alpha=0.810$; $\mathrm{T} 2 \alpha=0.827$ and demands hiding emotions T1 $\alpha=0.618$; T2 $\alpha=0.642$.

Leadership resources were measured with Polish version of the two COPSOQ II subscales [94] related to quality of leadership (e.g., To what extent would you say that your immediate superior is good at solving conflicts?) and trust in management (e.g., Does the management withhold important information from the employees?). Both subscales contained four items, with answers from 1 (Always or To a very large extent) to 5 (Never/Hardly ever or To a very small extent). The reliability of the scales was, respectively, for quality of leadership T1 $\alpha=0.908 ; \mathrm{T} 2 \alpha=0.908$ and for trust in management T1 $\alpha=0.690 ; \mathrm{T} 2 \alpha=0.736$.

The choice of these two variables as resource leadership indicators based on the typology of job resources proposed by Berthelsen et al. [61]. Quality of leadership includes task-oriented behaviors, such as initiating tasks, planning the work of subordinates, stimulating them to work and the ability to solve conflicts in a group. Trust in management, in turn includes relational-oriented behaviors, such as sharing information with subordinates, caring for subordinates, creating an atmosphere conducive to openly expressing one's views and feelings.

Exhaustion was measured with the Oldenburg Burnout Inventory subscale [10], in Polish version [95]. It consists of eight items related to different negative states in work, such as fatigue, resource depletion, strain, decreased ability to regenerate (e.g., After work, I tend to need more time than in the past in order to relax and feel better). A 5-point response scale ranged from 1 (I completely disagree) to 5 (I completely agree). The level of reliability for the scale is $\mathrm{T} 1 \alpha=0.784 ; \mathrm{T} 2 \alpha=0.780$

\subsection{Analytical Procedure}

Data analysis was carried out using the IBM SPSS 27 statistical software package with the additional PROCESS macro by A. F. Hayes. Moreover, SPSS AMOS 27 program was used to perform confirmatory factor analysis.

At the beginning, basic data concerning analyzed variables (M, SD, SKE, KUR) were presented, and the difference between the first and the second measurement was also verified. The analysis of the results of the measures of skewness and kurtosis was carried out to determine whether they fall within the range from -1 to +1 , which allows to confirm the normal distribution of the analyzed variables [96]. In order to determine the factor accuracy and estimate the parameters of fit, a confirmatory factor analysis (CFA) of the tools used in the structure proposed by its authors was also carried out. At the beginning, the data were analyzed for multivariate outliers with the Mahalanobis distance method, 
and when the result turned out to be statistically significant at the level of $p=0.001$, it was eliminated from the analysis. When analyzing the results of the CFA, among other things, the following were applied: the goodness of fit (GFI), the Tucker-Lewis index (TLI), the comparative fit index (CFI), for which a score $\geq 0.90$ suggests an acceptable level of fit. In addition, the following were applied: root mean square error of approximation (RMSEA) and standardized root mean square residual (SRMR), for which a value $<0.10$ indicates an acceptable level of fit. After estimating the measurement models of the questionnaires, the internal consistency of the subscales was analyzed using the Cronbach's Alpha. The following step was the linear correlation analysis in order to check to what extent quantitative and emotional demands at work and leadership resources (quality of leadership and trust in management) relate to the level of exhaustion in the first and the second measurement. The last stage of analysis was to test the moderations model to determine to what extent different types of job demands measured in the first measurement relate to exhaustion after a year (measurement 2), and whether the quality of leadership (moderator 1) and trust in management (moderator 2) measured in the first measurement, moderate the relationship in question simultaneously. A moderation analysis was selected as it enables assessing whether a certain level of quality and trust distinguished on the basis of standardized data allows to change the relationship between job demands and exhaustion level (Figure 1). To test the theoretical model, PROCESS macro model 3 [97] was selected, which allows for the introduction of two moderators simultaneously and the verification of interactions between factors in the entire model, as well as the presentation of individual conditional effects for individual levels of the first (quality of leadership) and the second (trust in management) moderator. $p<0.05$ was applied as the level of significance, and for the moderation and conditional effects, confidence intervals were applied as a more accurate way of probability estimation $[97,98]$.

\section{Results}

The analysis of descriptive statistics of the presented variables shows that each distribution of results in terms of the level of skewness and kurtosis falls within a range from -1 to 1 , which allows the fulfillment of the assumption of the analyzed variables distribution normality (Table 1) [96]. Comparing the measurements presents a number of significant differences. The level of perceived exhaustion, quantitative, as well as emotional demands turned out to be significantly higher in the first measurement, while trust in management and quality of leadership were rated higher by the respondents in the second measurement, which may constitute an argument that confirms the lower level of exhaustion also in the second measurement (Table 1).

Table 1. Descriptive statistics for measurements 1 and 2, and comparison of measurements.

\begin{tabular}{|c|c|c|c|c|c|c|c|c|c|c|c|}
\hline & \multicolumn{4}{|c|}{ Measurement 1} & \multicolumn{4}{|c|}{ Measurement 2} & & & \multirow[b]{2}{*}{ d } \\
\hline & $\mathbf{M}$ & SD & SKE & KUR & $\mathbf{M}$ & SD & SKE & KUR & & & \\
\hline (EX) Exhaustion & 2.18 & 0.51 & -0.383 & -0.300 & 2.13 & 0.49 & -0.326 & -0.049 & 2.968 & 0.003 & 0.095 \\
\hline (QL) Quality of leadership & 60.81 & 20.36 & -0.208 & 0.096 & 64.38 & 19.57 & -0.143 & 0.015 & 5.431 & $<0.001$ & 0.179 \\
\hline (TM) Trust in management & 61.56 & 16.12 & 0.006 & 0.413 & 64.41 & 17.35 & 0.002 & -0.390 & 5.233 & $<0.001$ & 0.170 \\
\hline (QD) Quantitative demands & 35.01 & 16.81 & 0.179 & -0.146 & 33.30 & 16.93 & -0.034 & -0.544 & 3.014 & 0.003 & 0.101 \\
\hline (ED) Emotional demands & 62.45 & 21.26 & -0.344 & -0.357 & 60.57 & 21.79 & -0.273 & -0.393 & 2.920 & 0.004 & 0.087 \\
\hline (HE) Hiding emotions demands & 58.98 & 21.58 & -0.226 & -0.313 & 59.54 & 21.10 & -0.101 & -0.349 & 0.808 & 0.419 & 0.026 \\
\hline
\end{tabular}

Note. M-Mean, SD—Standard deviation, SKE—Skewness, KUR—Kurtosis, $t$ - $t$-test result, $p$-Significance level, d—Cohen effect size.

The results obtained using CFA (Table A1 in Appendix A) indicate a good fit with the Job demand and Leadership resources data in measure one and two, as the results of each of the assumed parameters fall within the assumed criteria. For Exhaustion, the first and second measurement results for RMSEA and TLI are slightly outside the specified level. The mentioned discrepancy is not high and the other parameters such as SRMR, GFI and CFI meet the criteria hence the results can be accepted as acceptable (Table A1). 
A further analysis is the linear relationship presented in Table 2 between demands at work and attitude to superiors, and exhaustion in the first and the second measurement.

Table 2. Correlation matrix between job demands, leadership resources and exhaustion in measurements 1 and 2 .

\begin{tabular}{lcc}
\hline & Measurement 1 & Measurement 2 \\
\cline { 2 - 3 } & Exhaustion (EX1) & Exhaustion (EX2) \\
\hline (QL) Quality of leadership & $-0.313^{* *}$ & $-0.347^{* *}$ \\
(TM) Trust in management & $-0.370^{* *}$ & $-0.399^{* *}$ \\
(QD) Quantitative demands & $0.421^{* *}$ & $0.431^{* *}$ \\
(ED) Emotional demands & 0.024 & $0.021^{* *}$ \\
(HE) Hiding emotions demands & $0.131^{* *}$ & $0.081^{* *}$ \\
* $^{* *}-p<0.001$. & &
\end{tabular}

The results for both measurements are consistent with each other, i.e., quantitative demands constitute the strongest factor related to exhaustion in both measurements (Table 2). In the case of hiding emotions demands, it is also an important factor related to exhaustion. On the other hand, emotional demands turned out not to significantly correlate with exhaustion. The results obtained from the correlation of job demands factors with exhaustion partially support the first hypothesis which indicates a significant relationship between job demands and exhaustion, which was confirmed for two of the three variables.

According to project assumptions, quality of leadership and trust are important protective factors of exhaustion, out of which trust in management is a stronger protecting factor. On the basis of the analysis of differences between the measurements and a correlation matrix, it is possible to notice a significant relationship between the perceived level of job demands, as well as quality of leadership and trust in management with exhaustion.

The last stage of data analysis assumed verifying to what extent quality of leadership and superior trust in the first measurement, which, as presented in the previous analyzes, are significantly related to exhaustion, will be able to moderate a relationship between job demands in the first measurement and exhaustion in the second measurement. To verify the theoretical model, the process macro [97] model 3 was applied. Standardized data was used for the analysis, so that the presentation of results could be compared between particular effects. A number of analyzes were carried out in this manner, the fixed point of which was a dependent variable of exhaustion from the second measurement, and moderators in the form of quality of leadership and trust in management from the first measurement. The independent variables included subsequently quantitative, emotional and hiding emotions demands. Table 3 shows the significance level of each model for individual demand types, as well as the significance level of interactions between the independent variable and the moderators. Each of the estimated models is statistically significant, however, to confirm the existence of a significant moderation analysis, a significant interaction of variables is also necessary [97], which turned out to be confirmed exclusively in the case of quantitative demands (Table 3 ).

Table 3. Results of the moderation analysis for (QL) quality of leadership and (TM) trust in management as moderators for different types of job demands in predicting (EX) exhaustion.

\begin{tabular}{|c|c|c|c|c|}
\hline Variable & $\begin{array}{l}\text { Significance of the Model } \\
\text { Significance of the Interaction }\end{array}$ & $\mathbf{F}$ & $p$ & $\mathbf{R}^{2}$ \\
\hline \multirow{2}{*}{ (QD) quantitative demands } & model & 58.0285 & $<0.001$ & \multirow[t]{2}{*}{0.2521} \\
\hline & interaction for quantitative demands & 3.8993 & 0.0485 & \\
\hline \multirow{2}{*}{ (ED) emotional demands } & model & 54.9471 & $<0.001$ & \multirow[t]{2}{*}{0.2418} \\
\hline & interaction for emotional demands & 2.1513 & 0.1427 & \\
\hline \multirow{2}{*}{ (HE) hiding emotions demands } & model & 54.4765 & $<0.001$ & \multirow[t]{2}{*}{0.2405} \\
\hline & interaction for hiding emotions demands & 0.4685 & 0.4938 & \\
\hline
\end{tabular}

Note. F-ANOVA result, model fit level, $p$-Significance level, $\mathrm{R}^{2}$-Effect size. 
In relation to the above scores, a moderation analysis was presented for quantitative demands, since the results of interaction effect for the remaining variables had not confirmed the existence of moderation effect (Table 3).

In the case of the described moderation analysis for quantitative demands, all conditional effects for each level of both moderators are statistically significant (Table 4).

Table 4. Conditional effect of quantitative demands on exhaustion at values of (QL) quality of leadership and (TM) trust in management.

\begin{tabular}{|c|c|c|c|c|c|}
\hline Moderator 1 & Moderator 2 & $\mathrm{SE}$ & $p$ & LLCI & ULCI \\
\hline (QL) Quality of Leadership & (TM) Trust in Management & & & & \\
\hline (QL) M - 1SD & (TM) $\mathrm{M}-1 \mathrm{SD}$ & 0.0812 & 0.0422 & 0.0029 & 0.1596 \\
\hline (QL) M - 1SD & (TM) M & 0.1408 & 0.0005 & 0.0622 & 0.2194 \\
\hline (QL) M - 1SD & (TM) M + 1SD & 0.2004 & 0.0022 & 0.0720 & 0.3288 \\
\hline (QL) M & (TM) M - 1SD & 0.1078 & 0.0114 & 0.0243 & 0.1913 \\
\hline (QL) M & (TM) M & 0.1299 & 0.0000 & 0.0748 & 0.1851 \\
\hline (Q̄L) M & (TM) $M+1 S D$ & 0.1521 & 0.0002 & 0.0735 & 0.2306 \\
\hline (QL) M + 1SD & (TM) M - 1SD & 0.1344 & 0.0389 & 0.0069 & 0.2618 \\
\hline (QL) $\mathrm{M}+1 \mathrm{SD}$ & (TM) $\mathrm{M}$ & 0.1190 & 0.0048 & 0.0365 & 0.2016 \\
\hline (QL) M + 1SD & $(\mathrm{TM}) \mathrm{M}+1 \mathrm{SD}$ & 0.1037 & 0.0138 & 0.0212 & 0.1863 \\
\hline
\end{tabular}

Note. M - 1SD—Results at less than one standard deviation from the standardized mean; M-Results at the standardized average level; $\mathrm{M}+1 \mathrm{SD}$-Results at above one standard deviation from the standardized mean; SE-Standardized estimate; $p$-Significance level; LLCI—Lower level confidence interval; ULCI-Upper level confidence interval.

Figure 2 shows a relationship between perceived quantitative demands and exhaustion for a low level of assessed quality and trust, medium and high levels of assessed quality and trust. It is worth noting that in the case of employees who rated both quality level and confidence level above one standard deviation from the average, the exhaustion level was the lowest, and it also increased at the slowest pace along with the increase of quantitative demands (Figure 2). On the other hand, in a situation where employees assessed both quality level and trust level below one standard deviation from the average, the exhaustion level was the highest (Figure 2). The results of the moderated moderation analysis presented here confirm the second hypothesis, which assumes that leadership resources in the form of (QL) quality of leadership and (TM) trust in management are significant moderators of the relationship between job demands and exhaustion. Participants who reported high levels of (QL) quality of leadership and (TM) trust in management have lower levels of exhaustion than those who believe that leadership resources are at a low level. In addition, as the level of job demands increases, the level of exhaustion among those who rate leadership resources highly is also the lowest (Figure 2)

An attempt was also made to answer a question what moderator is a stronger protective factor in a situation when the level of the other moderator is below one deviation from the average. Both cross effects turned out to be significant (Table 4). In a situation where employees assess their trust above one standard deviation from the average, and quality of leadership below one standard deviation from the average, the effect is stronger than in the reverse configuration of results (Table 4, Figure 3), which means that if one factor is at a high level and the other is at a low level, the high level of trust protects against exhaustion more (Figure 3). 


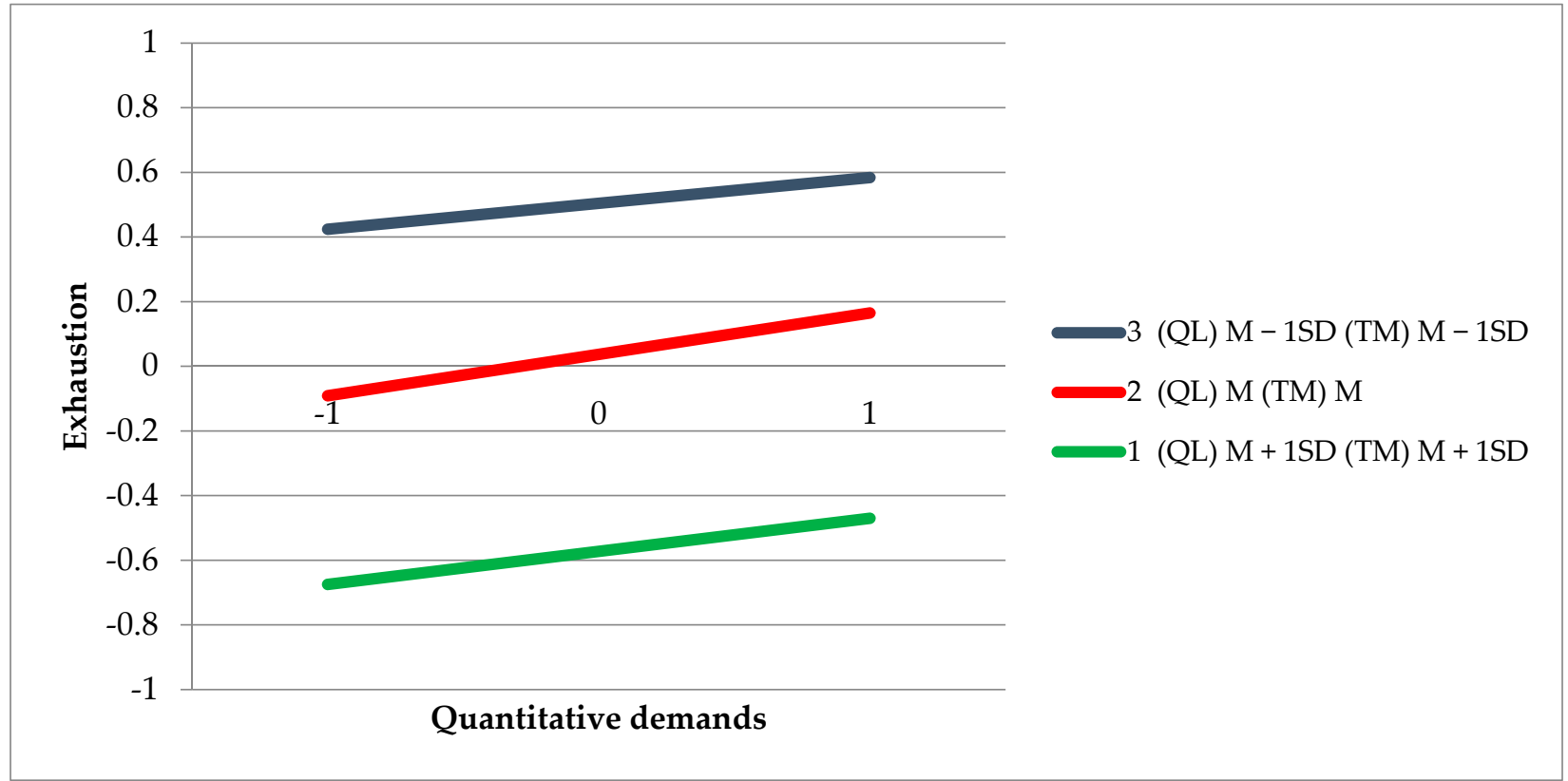

Figure 2. Conditional effect of quantitative demands on exhaustion at: 1-High values of (QL) quality of leadership and high values of (TM) trust in management, 2-Mean values of (QL) and mean values of (TM), 3-Low values of (QL) and low values of (TM). The figure shows the standardized results.

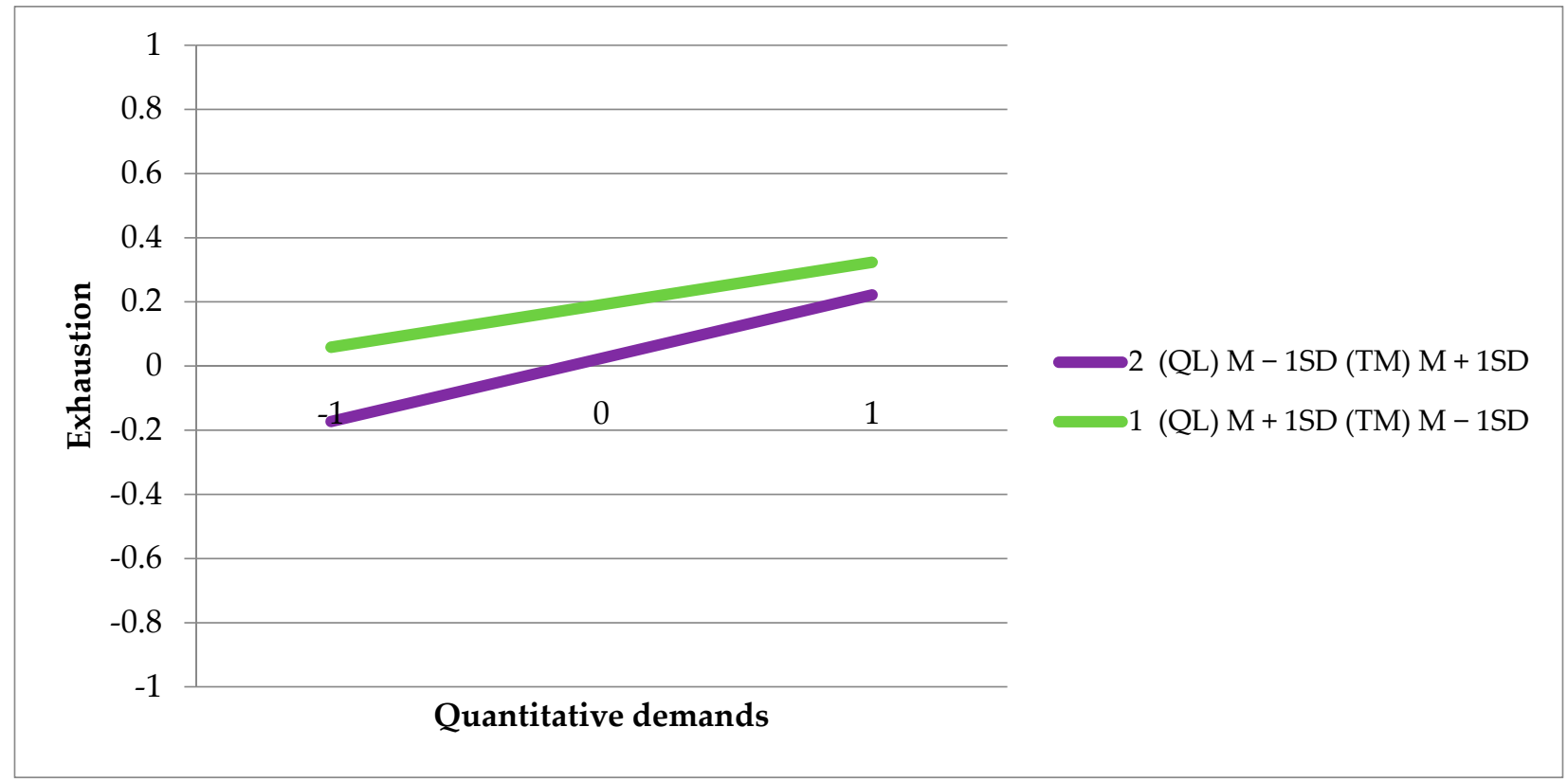

Figure 3. Conditional effect of quantitative demands on exhaustion at: 1 - High values of (QL) quality of leadership and low values of (TM) trust in management, 2-Low values of (QL), high values of (TM). The figure shows the standardized results.

\section{Discussion}

The present study is among the first attempting to elucidate the levels of exhaustion among front-line healthcare workers in the pandemic time. We investigated whether the one-year cross-lagged relations between two kinds of job demands (including quantitative and emotional demands) and exhaustion is moderated by two leadership resourcesquality of leadership (related to task-oriented style) and supervisor trust (related to relationship-oriented style). In particular, it was hypothesized that the negative effect of the two job demands is particularly harmful for healthcare workers in the COVID-19 
pandemic, that carries (itself) additional risk factors related and unrelated to job content. We also anticipated that this negative influence would be reduced by the two leadership resources. In other words, those healthcare workers who believe in the high level of their superiors' skills in planning, managing and supervising the work of the workers team, and feel that their superiors care for, support and trust them should be the least exhausted, after one year.

The results of our research confirmed that quantitative demands covering workload, work intensity and time pressure intensify exhaustion of healthcare workers, measured one year later. The findings are consistent with the JD-R model and with the results of previous studies [60]. The relationship between emotional demands and exhaustion turned out to be more complex. Demands associated with burdensome relationship with patient, care and emotional engagement in the patient's personal problems were not connected with higher level of exhaustion, while demands for hiding emotions (e.g., during contact with potentially infectious material, including blood, secretions, excreta, contact with chronic diseases and death) seemed to exhaust healthcare workers, however their connections with exhaustion were weaker than for quantitative demands.

There are several explanations as to why not all emotional demands resulted in an increase in exhaustion. One of them relates to the challenge-hindrance occupational stress model and to the division into "good" and "bad" stressors [88,99]. In general, hindrance stressors include job demands, which are viewed as barriers to goal accomplishment, while challenge stressors may have potential gains for the employee. They create broad opportunities for development and improvement of one's job performance or self-efficacy and are often a chance for promotion or a pay rise. They are usually associated with a sense of fulfilment and job satisfaction, as the employee is able to overcome difficulties at work or solve demanding problems. A few studies supported that healthcare are especially predisposed to perceiving emotional demands as challenge stressors [99,100]. For example, Bakker and Sanz-Vergel [100] compared to which group of stressors (challenge or hindrance) are ascribed different types of job demands by nurses. It turned out that time pressure is perceived as a hindrance because it means that there is not enough time to provide proper care to patients, which is conducive to professional fatigue and frustration. Conversely, emotional demands in nursing work (i.e., frequency of interactions with patients, and handling patient emotions and those of their family) represent "the heart of the work" and are considered a challenge [100].

Indeed, although a large part of studies on different professional groups have confirmed positive relations between emotional demands and job burnout $[9,48,52,54,55]$, some of them showed that, in the case of social service workers, emotional demands do not always play a role in experience of job burnout [101,102]. Of additional importance is probably the fact that these longitudinal studies were conducted in the period of high incidence of COVID-19. On one hand, the pandemic has made the work of medical personnel particularly demanding and strenuous, often carried out overtime, day and night, with a shortage of staff and equipment. On the other hand, it raised the rank of medical profession in society and solidarity with doctors, paramedics or nurses. Pandemic could also strengthen the sense of work importance and meaningfulness from perspective of medical staff and making it a kind of mission.

The lack of negative consequences of emotional demands (contrary to quantitative demands) can also be explained by the so-called "Mother Teresa effect" [103], according to which helping, solving problems and serving others are activities that stimulate and develop personal spirituality. A study has shown that spirituality can serve as a protective factor in relieving compassionate fatigue among professional mental health providers working under stressful conditions in Kenya, as well as increasing their job satisfaction [103]. Thus, it can be said that service to other people and inner development are mutually reinforcing processes. The medical professions usually attract people who are driven by a sense of mission and a desire to do good. Some researchers [104] indicate that the most important reasons for choosing this profession are helping others, doing interesting and 
challenging work, and working closely with people in need. Indeed, caring for others, engaging in their problems and changing their lives can be a source of positive emotions for these employees [105]. Moreover, according to a qualitative survey, nurses (for example) are able to resist emotional demands and "are aware that they must actively work on their emotions" [106] (p. 92); therefore, we assume that emotional demands may not necessarily be stressful but may instead be rewarding and act as challenges for healthcare workers. In a diary study lasting for three consecutive working weeks, it was found that emotional job demands strengthened the effect of personal resources on weekly well-being of nurses, whereas work pressure undermined this effect [100].

The moderational function of leadership resources has been largely confirmed. Both quality of leadership relates to job competences of leaders, as well as trust in management relates to team relations building buffer the harmful impact of quantitative (but not emotional) demands on exhaustion. Moreover, these two types of leadership resources (i.e., task- and relationship-oriented) have been found to interact with each other and together neutralize the detrimental effects of quantitative demands. Specifically, the lowest level of exhaustion was observed among those healthcare workers who had had the highest level of leadership quality the strongest confidence in their superiors. In management sciences, a distinction is made between competence-based (cognitive) trust and integrity-based (affective) trust (e.g., $[107,108])$. The first type of trust is based on the expectation that the interaction partner (e.g., leader) has the knowledge, technical skills, experience and integrity necessary to perform their duties [109]. The second one is based on the expectation that the partner's motives are sincere, fair and upright [110]. The combination of these two types of trust in the leader largely satisfies the need for the safety of subordinates [111], and thus may reduce their level of job stress and exhaustion. Our research has also shown that trust in management minimizes the negative impact of quantitative demands on exhaustion to a greater extent than quality of leadership. Connelly, Crook, Combs, Ketchen and Aguinis [108], based on the results of meta-analytical modeling of the structural equation based on data from 150 samples, state that an integrity-based trust is 10 times more important in developing positive inter-organizational relations and increasing employee productivity than competence-based trust. Perhaps, employees who are convinced of the leader's sincere intentions and a sense of loyalty to him better handle the workload.

Looking at the results obtained in a slightly broader, intercultural context, it can be concluded that they are partially consistent with the results of some studies conducted in other countries and on different occupational groups. They confirm that "good" leadership modifies the negative effect of quantitative demands but does not affect emotional demands. For example, a cross-sectional study on the school employees' group in the Northeastern U.S. found that transformational leadership (i.e., both task-oriented and relationship-oriented leadership) does not moderate the association between the student violence against school employees (victimization perceived as emotional demand) and burnout [112]. Similarly, in two longitudinal study quality of leadership (task-oriented leadership) did not buffer the hazardous impact of emotional demands on risk of longterm sickness absence (LTSA) in a group of 25,416 Danish employees [113] and on mental health (measured with risk of antidepressant treatment) in a group of 6096 Danish and 3411 Swedish employees [114]. On the other hand, the cross-sectional research conducted by Engel et al. [115] showed that a positive leadership climate (relationship-oriented leadership) prevented emotional exhaustion and also reduced the negative effect of work effort in the group of German police officers. Similar results were observed in Chinese study on 2636 schoolteachers [86]. Therefore, it can be said that the results on the moderating function of leadership resources observed in the presented study on Polish health-care workers are confirmed in the international literature.

\section{Limitations}

This research is not without limitations. When considering generalizability, it should be noted that the results of this study were obtained from a sample of healthcare workers- 
doctors, paramedics and nurses, particularly. The observed regularities relate to this professional groups only and should not be generalized to other occupations and market sectors. Next issue is the gender disproportion in the research sample. Women were overrepresented, because the number of women in this occupational field is significantly greater. For the male population, in traditionally typical male occupations, the results would be perhaps different. In the presented study, only two selected leadership resources were taken into consideration. In particular, the role of leadership styles was not investigated. Therefore, it is worthwhile to incorporate other types of leadership behavior into future research and to address them more comprehensively. It is also worth checking the effects of other types of work demands (e.g., cognitive demands), both for job performance as well for employees' well-being. Another issue is that the research was conducted during the COVID-19 pandemic; hence, some responses (e.g., related to exhaustion) may be biased by the specificity of the current situation. During a pandemic, the organization of work and the level of job demands are different from traditional ones. For example, healthcare workers face a great amount of unusual job-related stressors, including more patients, higher workload, more intensive care, staff shortages, insufficient equipment and other [2]. These unusual job conditions may have a significant impact on the results obtained.

\section{Conclusions}

Summarizing the results obtained in the study, it should be noted that in the case of analyzed job demands, (QD) Quantitative demands are the most strongly associated with exhaustion over the year, followed by (HE) Hiding emotions demands, while (ED) Emotional demands turned out not to be significantly associated with exhaustion (Table 2). In furthermore, (QL) Quality of leadership and (TM) Trust in management have been shown to significantly buffer the relationship between job demands and exhaustion, leading ultimately to the lowest levels of exhaustion among individuals whose trust in superiors and belief in the quality of leadership is high (Figure 2). The conducted analysis also allows us to indicate which of the leadership resources factors is a stronger moderator. It turns out that trust in management is the more important factor (Figure 3).

Apart from the cognitive values, this study has also some practical implications. By identifying job factors responsible for the development of exhaustion and resources that reduce the risk of its occurrence, more effective programs and interventions that support coping with occupational stress by health-care workers can be designed. For example, given the importance of leadership resources, health institutions can focus on building a culture that enhances trust and cooperation between supervisors and subordinates, and builds positive relationships between doctors, nurses and other medical personnel. Knowledge that the imbalance between job demands and personal resources leads to exhaustion can encourage the design of appropriate development paths: for example, offering personal skills enhancement for workers who are low in personal resources, and team-building interventions for groups of highly effective individuals who have an insufficient level of job resources.

Author Contributions: Ł.B. and D.Ś. made major contributions to the conception development and design of the work; Moreover, Ł.B. and D.Ś. were responsible for methodology, validation, formal analysis, investigation, data curation, resources and funding acquisition; Ł.B., D.Ś. and K.G. concerned writing — original draft preparation, writing—review and editing; D.Ś. has taken care of project administration, visualization and supervision. All authors have read and agreed to the published version of the manuscript.

Funding: This paper is based on the results of a research task carried out within the scope of the five stage of the National Programme "Improvement of safety and working conditions" partly supported in 2020-2022 - within the scope of research and development-by National Centre for Research and Development. 
Institutional Review Board Statement: The study was conducted according to the guidelines of the Declaration of Helsinki and approved by the Ethics Committee at the Cardinal Stefan Wyszyński University in Warsaw (KEiB-31/2020 from 10 June 2020).

Informed Consent Statement: Informed consent was obtained from all subjects involved in the study.

Data Availability Statement: The datasets generated for this study are available on request to the corresponding author.

Conflicts of Interest: The authors declare no conflict of interest.

\section{Appendix A}

Table A1. Model adequacy and goodness of fit indices of the models tested using first- order confirmatory factor analysis.

\begin{tabular}{|c|c|c|c|c|c|c|c|c|c|c|}
\hline Models & $X^{2}$ & $d f$ & RMSEA & PClose & 90 LLCI & 90 ULCI & SRMR & TLI & GFI & CFI \\
\hline Job demand-Measurement 1 & 344.456 & 40 & 0.070 & 0.000 & 0.063 & 0.077 & 0.0507 & 0.918 & 0.961 & 0.940 \\
\hline Job demand-Measurement 2 & 241.387 & 40 & 0.067 & 0.000 & 0.059 & 0.075 & 0.0552 & 0.924 & 0.961 & 0.945 \\
\hline Leadership resources-Measurement 1 & 150.337 & 19 & 0.066 & 0.000 & 0.057 & 0.076 & 0.0311 & 0.968 & 0.976 & 0.978 \\
\hline Leadership resources-Measurement 2 & 165.250 & 19 & 0.081 & 0.000 & 0.070 & 0.093 & 0.0426 & 0.954 & 0.964 & 0.969 \\
\hline Exhaustion-Measurement 1 & 330.281 & 16 & 0.110 & 0.000 & 0.100 & 0.121 & 0.0749 & 0.860 & 0.954 & 0.920 \\
\hline Exhaustion-Measurement 2 & 252.283 & 16 & 0.116 & 0.000 & 0.104 & 0.129 & 0.0785 & 0.851 & 0.948 & 0.915 \\
\hline
\end{tabular}

Note. Job demands include: (QD) Quantitative demands, (ED) Emotional demands and (HE) Hiding emotions demands, Leadership resources include: (QL) Quality of leadership and (TM) Trust in management, Exhaustion include: (EX) Exhaustion, CFA: RMSEA root mean square error of approximation, PClose p of Close Fit, 90 LLCI Confidence intervals, 90 ULCI Confidence intervals, SRMR standardized root mean square residual, TLI Tucker-Lewis index, GFI Goodness of Fit, CFI the comparative fit index. The re-specifications of models were achieved based on error covariance modification indices.

\section{References}

1. Abdulah, D.M.; Musa, D.H. Insomnia and stress of physicians during COVID-19 outbreak. Sleep Med. X 2020, 2, 100017. [CrossRef]

2. Fiorillo, A.; Gorwood, P. The consequences of the COVID-19 pandemic on mental health and implications for clinical practice. Eur. Psychiatry J. Assoc. Eur. Psychiatr. 2020, 63, e32. [CrossRef]

3. Baka, Ł. Coronavirus anxiety and exhaustion among Polish front-line healthcare workers-The mediation effect of insomnia. Int. J. Occup. Med. Environ. Health 2021, 34, 263-273. [CrossRef]

4. Jimmieson, N.L.; Tucker, M.K.; Walsh, A.J. Interaction effects among multiple job demands: An examination of healthcare workers across different contexts. Anxiety Stress Coping 2017, 30, 317-332. [CrossRef]

5. Moreno-Jiménez, J.E.; Blanco-Donoso, L.M.; Chico-Fernández, M.; Belda Hofheinz, S.; Moreno-Jiménez, B.; Garrosa, E. The job demands and resources related to COVID-19 in predicting emotional exhaustion and secondary traumatic stress among health professionals in Spain. Front. Psychol. 2021, 12, 564036. [CrossRef]

6. Hobfoll, S.E. Conservation of resources theory: Its implication for stress, health, and resilience. In The Oxford Handbook of Stress, Health, and Coping; Oxford Library of Psychology; Oxford University Press: New York, NY, USA, 2011; pp. $127-147$.

7. Nguyen, L.H.; Drew, D.A.; Graham, M.S.; Joshi, A.D.; Guo, C.-G.; Ma, W.; Mehta, R.S.; Warner, E.T.; Sikavi, D.R.; Lo, C.H.; et al. Risk of COVID-19 among front-line health-care workers and the general community: A prospective cohort study. Lancet Public Health 2020, 5, e475-e483. [CrossRef]

8. Pappa, S.; Ntella, V.; Giannakas, T.; Giannakoulis, V.G.; Papoutsi, E.; Katsaounou, P. Prevalence of depression, anxiety, and insomnia among healthcare workers during the COVID-19 pandemic: A systematic review and meta-analysis. Brain. Behav. Immun. 2020, 88, 901-907. [CrossRef]

9. Van Vegchel, N.; de Jonge, J.; Söderfeldt, M.; Dormann, C.; Schaufeli, W. Quantitative versus emotional demands among swedish human service employees: Moderating effects of job control and social support. Int. J. Stress Manag. 2004, 11, 21-40. [CrossRef]

10. Demerouti, E.; Bakker, A.B.; Nachreiner, F.; Schaufeli, W.B. The job demands-Resources model of burnout. J. Appl. Psychol. 2001, 86, 499-512. [CrossRef]

11. Fu, W.; Wang, C.; Zou, L.; Guo, Y.; Lu, Z.; Yan, S.; Mao, J. Psychological health, sleep quality, and coping styles to stress facing the COVID-19 in Wuhan, China. Transl. Psychiatry 2020, 10, 225. [CrossRef] [PubMed]

12. Dewa, C.S.; Loong, D.; Bonato, S.; Trojanowski, L. The relationship between physician burnout and quality of healthcare in terms of safety and acceptability: A systematic review. BMJ Open 2017, 7, e015141. [CrossRef] [PubMed]

13. Hall, L.H.; Johnson, J.; Watt, I.; Tsipa, A.; O'Connor, D.B. Healthcare staff wellbeing, burnout, and patient safety: A systematic review. PLoS ONE 2016, 11, e0159015. [CrossRef]

14. Bronkhorst, B.; Tummers, L.; Steijn, B.; Vijverberg, D. Organizational climate and employee mental health outcomes: A systematic review of studies in health care organizations. Health Care Manag. Rev. 2015, 40, 254-271. [CrossRef] [PubMed] 
15. Kuoppala, J.; Lamminpää, A.; Liira, J.; Vainio, H. Leadership, job well-being, and health effects-A systematic review and a meta-analysis. J. Occup. Environ. Med. 2008, 50, 904-915. [CrossRef]

16. Montano, D.; Reeske, A.; Franke, F.; Hüffmeier, J. Leadership, followers' mental health and job performance in organizations: A comprehensive meta-analysis from an occupational health perspective. J. Organ. Behav. 2017, 38, 327-350. [CrossRef]

17. Skakon, J.; Nielsen, K.; Borg, V.; Guzman, J. Are leaders' well-being, behaviours and style associated with the affective well-Being of Their Employees? A systematic review of three decades of research. Work Stress 2010, 24, 107-139. [CrossRef]

18. Koff, S.Z. Nursing in the European Union: Anatomy of a Profession; Routledge: New York, NY, USA, 2017.

19. OECD; European Union. Health at a Glance: Europe 2020: State of Health in the EU Cycle; OECD Publishing: Paris, France, 2020.

20. Simon, M.; Kümmerling, A.; Hasselhorn, H. Work-home conflict in the european nursing profession. Int. J. Occup. Environ. Health 2004, 10, 384-391. [CrossRef]

21. Maxwell, S.E.; Cole, D.A.; Mitchell, M.A. Bias in cross-sectional analyses of longitudinal mediation: Partial and complete mediation under an autoregressive model. Multivar. Behav. Res. 2011, 46, 816-841. [CrossRef]

22. Hasselhorn, H.; Tackenberg, P.; Müller, H. Work Conditions and Intent to Leave the Profession Among Nursing Staff in Europe; Report No 7:2003; SALTSA: Stockholm, Sweden, 2003.

23. Naczelna Izba Pielęgniarek i Położnych-Samorząd [Main Chamber of Nurses and Midwives-Local Government]. Available online: https:/ / nipip.pl/ (accessed on 6 September 2021).

24. Giusti, E.M.; Pedroli, E.; D'Aniello, G.E.; Stramba Badiale, C.; Pietrabissa, G.; Manna, C.; Stramba Badiale, M.; Riva, G.; Castelnuovo, G.; Molinari, E. The psychological impact of the COVID-19 outbreak on health professionals: A cross-sectional study. Front. Psychol. 2020, 11, 1684. [CrossRef] [PubMed]

25. ICN. International Council of Nurses. Available online: https://www.icn.ch/homepage (accessed on 28 July 2021).

26. ICN. ICN Reaction: WHO DG Dr Tedros Confirms at Least 115,000 Health Workers Have Died Due to Pandemic. 2021. Available online: https:/ / www.icn.ch/news/icn-reaction-who-dg-dr-tedros-confirms-least-115000-health-workers-have-dieddue-pandemic (accessed on 25 July 2021).

27. Statista. Poland: COVID-19 Infections and Deaths in Healthcare 2021, by Profession. Available online: https: / / www.statista. com/statistics/1246201/poland-covid-19-infections-and-deaths-in-healthcare/ (accessed on 25 July 2021).

28. Karasek, R.A. Job demands, job decision latitude, and mental strain: Implications for job redesign. Adm. Sci. Q. 1979, 24, 285. [CrossRef]

29. Meijman, T.F.; Mulder, G. Psychological aspects of workload. In Handbook of Work and Organizational: Work Psychology, 2nd ed.; Psychology Press: Hove, UK, 1998; Volume 2, pp. 5-33.

30. Lee, R.T.; Ashforth, B.E. A meta-analytic examination of the correlates of the three dimensions of job burnout. J. Appl. Psychol. 1996, 81, 123-133. [CrossRef]

31. McMahan, J. A Meta-Analytic Examination of the Dimensions of Teacher Burnout and Demand and Resource Correlates. Master's Thesis, University of Tennessee, Knoxville, TN, USA, 2003.

32. Alarcon, G.M. A meta-analysis of burnout with job demands, resources, and attitudes. J. Vocat. Behav. 2011, 79, 549-562. [CrossRef]

33. Aronsson, G.; Theorell, T.; Grape, T.; Hammarström, A.; Hogstedt, C.; Marteinsdottir, I.; Skoog, I.; Träskman-Bendz, L.; Hall, C. A systematic review including meta-analysis of work environment and burnout symptoms. BMC Public Health 2017, 17, 264. [CrossRef]

34. Trufelli, D.C.; Bensi, C.G.; Garcia, J.B.; Narahara, J.L.; Abrão, M.N.; Diniz, R.W.; Miranda, V.D.C.; Soares, H.P.; Del Giglio, A. Burnout in cancer professionals: A systematic review and meta-analysis. Eur. J. Cancer Care 2008, 17, 524-531. [CrossRef] [PubMed]

35. Lim, N.; Kim, E.; Kim, H.; Yang, E.; Lee, S.M. Individual and work-related factors influencing burnout of mental health professionals: A meta-analysis. J. Employ. Couns. 2010, 47, 86-96. [CrossRef]

36. Yates, M.; Samuel, V. Burnout in oncologists and associated factors: A systematic literature review and meta-analysis. Eur. J. Cancer Care 2019, 28, e13094. [CrossRef] [PubMed]

37. Oksanen, T.; Kouvonen, A.; Kivimäki, M.; Pentti, J.; Virtanen, M.; Linna, A.; Vahtera, J. Social capital at work as a predictor of employee health: Multilevel evidence from work units in Finland. Soc. Sci. Med. 2008, 66, 637-649. [CrossRef]

38. Söderfeldt, B.; Söderfeldt, M.; Muntaner, C.; O'Campo, P.; Warg, L.E.; Ohlson, C.G. Psychosocial work environment in human service organizations: A conceptual analysis and development of the demand-control model. Soc. Sci. Med. 1996, 42, 1217-1226. [CrossRef]

39. The World Bank. Employment in Services (\% of Total Employment) (Modeled ILO Estimate). 2021. Available online: https: / / data.worldbank.org/indicator/SL.SRV.EMPL.ZS (accessed on 25 July 2021).

40. Zapf, D. Emotion work and psychological well-being: A review of the literature and some conceptual considerations. Hum. Resour. Manag. Rev. 2002, 12, 237-268. [CrossRef]

41. Moskowitz, J.T. Emotion and coping. In Emotions: Currrent Issues and Future Directions; Emotions and Social Behavior; Guilford Press: New York, NY, USA, 2001; pp. 311-336.

42. Mayne, T.J. Emotions and health. In Emotions: Currrent Issues and Future Directions; Emotions and Social Behavior; Guilford Press: New York, NY, USA, 2001; pp. 361-397.

43. Gross, J. Emotional expression in cancer onset and progression. Soc. Sci. Med. 1989, 28, 1239-1248. [CrossRef] 
44. Kemeny, M.E.; Shestyuk, A. Emotions, the neuroendocrine and immune systems, and health. In Handbook of Emotions, 3rd ed.; Guilford Press: New York, NY, USA, 2008; pp. 661-675.

45. Consedine, N.S. Health-promoting and health-damaging effects of emotions the view from developmental functionalism. In Handbook of Emotions, 3rd ed.; Guilford Press: New York, NY, USA, 2008; pp. 676-690.

46. Beal, D.J.; Trougakos, J.P.; Weiss, H.M.; Green, S.G. Episodic processes in emotional labor: Perceptions of affective delivery and regulation strategies. J. Appl. Psychol. 2006, 91, 1053-1065. [CrossRef]

47. Hochschild, A.R. The Managed Heart: Commercialization of Human Feeling; University of California Press: Oakland, CA, USA, 2003.

48. Brotheridge, C.; Grandey, A. Emotional labor and burnout: Comparing two perspectives of "people work". J. Vocat. Behav. 2002, 60, 17-39. [CrossRef]

49. Berthelsen, H.; Westerlund, H.; Hakanen, J.J.; Kristensen, T.S. It is not just about occupation, but also about where you work. Community Dent. Oral Epidemiol. 2017, 45, 372-379. [CrossRef]

50. Wieclaw, J.; Agerbo, E.; Mortensen, P.B.; Burr, H.; Tüchsen, F.; Bonde, J.P. Work related violence and threats and the risk of depression and stress disorders. J. Epidemiol. Community Health 2006, 60, 771-775. [CrossRef] [PubMed]

51. Bakker, A.B.; Schaufeli, W.B.; Sixma, H.J.; Bosveld, W.; Dierendonck, D.V. Patient demands, lack of reciprocity, and burnout: A five-year longitudinal study among general practitioners. J. Organ. Behav. 2000, 21, 425-441. [CrossRef]

52. De Jonge, J.; Le Blanc, P.M.; Peeters, M.C.W.; Noordam, H. Emotional job demands and the role of matching job resources: A cross-sectional survey study among health care workers. Int. J. Nurs. Stud. 2008, 45, 1460-1469. [CrossRef] [PubMed]

53. Duarte, J.; Berthelsen, H.; Owen, M. Not all emotional demands are the same: Emotional demands from clients' or co-workers' relations have different associations with well-being in service workers. Int. J. Environ. Res. Public. Health 2020, 17, 7738. [CrossRef] [PubMed]

54. Näring, G.; Vlerick, P.; de Ven, B.V. Emotion work and emotional exhaustion in teachers: The job and individual perspective. Educ. Stud. 2012, 38, 63-72. [CrossRef]

55. Idris, M.A.; Dollard, M.F.; Yulita, Y. Psychosocial safety climate, emotional demands, burnout, and depression: A longitudinal multilevel study in the Malaysian private sector. J. Occup. Health Psychol. 2014, 19, 291-302. [CrossRef] [PubMed]

56. Lorente Prieto, L.; Salanova Soria, M.; Martínez Martínez, I.; Schaufeli, W. Extension of the job demands-resources model in the prediction of burnout and engagement among teachers over time. Psicothema 2008, 20, 354-360.

57. Sundin, L.; Hochwälder, J.; Lisspers, J. A longitudinal examination of generic and occupational specific job demands, and work-related social support associated with burnout among nurses in Sweden. Work Read. Mass 2011, 38, 389-400. [CrossRef]

58. Van de Ven, B.; van den Tooren, M.; Vlerick, P. Emotional job resources and emotional support seeking as moderators of the relation between emotional job demands and emotional exhaustion: A two-wave panel study. J. Occup. Health Psychol. 2013, 18, 1-8. [CrossRef]

59. Van de Ven, B.; Vlerick, P. Testing the triple-match principle among technology employees. Eur. J. Work Organ. Psychol. 2013, 22, 658-669. [CrossRef]

60. Bakker, A.B.; Demerouti, E. The job demands-resources model: State of the art. J. Manag. Psychol. 2007, 22, 309-328. [CrossRef]

61. Berthelsen, H.; Hakanen, J.J.; Westerlund, H. Copenhagen psychosocial questionnaire-A validation study using the job demandresources model. PLoS ONE 2018, 13, e0196450. [CrossRef] [PubMed]

62. Schaufeli, W.B.; Bakker, A.B. Job demands, job resources, and their relationship with burnout and engagement: A multi-sample study. J. Organ. Behav. 2004, 25, 293-315. [CrossRef]

63. Bean-Mellinger, B. Differences Between Task-Oriented Leaders \& Relational-Oriented Leaders. 2019. Available online: https:/ / smallbusiness.chron.com/differences-between-taskoriented-leaders-relationaloriented-leaders-35998.html (accessed on 28 July 2021).

64. Lewin, K.; Lippitt, R.; White, R.K. Patterns of aggressive behavior in experimentally created "social climates". J. Soc. Psychol. 1939, 10, 271-299. [CrossRef]

65. Fleishman, E.A.; Peters, D.R. Interpersonal values, leadership attitudes and managerial "success". Pers. Psychol. 1962, 15, 127-143. [CrossRef]

66. Likert, R. The Human Organization: Its Management and Values; McGraw-Hill: New York, NY, USA, 1967.

67. Fiedler, F.E. The contingency model: New direction for leadership utilization. J. Contemp. Bus. 1974, 3, 65-79.

68. Burns, J.M. Leadership; Harper \& Row: New York, NY, USA, 1978.

69. Fleishman, E.A.; Harris, E.F. Patterns of leadership behavior related to employee grievances and turnover. Pers. Psychol. 1962, 15, 43-56. [CrossRef]

70. Judge, T.A.; Piccolo, R.F.; Ilies, R. The forgotten ones? The validity of consideration and initiating structure in leadership research. J. Appl. Psychol. 2004, 89, 36-51. [CrossRef]

71. Rosenberg, S.; Nelson, C.; Vivekananthan, P.S. A multidimensional approach to the structure of personality impressions. J. Pers. Soc. Psychol. 1968, 9, 283-294. [CrossRef] [PubMed]

72. Wojciszke, B.; Dowhyluk, M.; Jaworski, M. Moral competence-related traits: How do they differ? Pol. Psychol. Bull. 1998, 29, 283-294.

73. Yukl, G. Effective leadership behavior: What we know and what questions need more attention. Acad. Manag. Perspect. 2012, 26, 66-85. [CrossRef]

74. Behrendt, P.; Matz, S.; Göritz, A.S. An integrative model of leadership behavior. Leadersh. Q. 2017, 28, 229-244. [CrossRef] 
75. Yammarino, F.J.; Spangler, W.D.; Bass, B.M. Transformational leadership and performance: A longitudinal investigation. Leadersh. Q. 1993, 4, 81-102. [CrossRef]

76. Gupta, V.K.; Huang, R.; Niranjan, S. A longitudinal examination of the relationship between team leadership and performance. J. Leadersh. Organ. Stud. 2010, 17, 335-350. [CrossRef]

77. Tse, H.H.M.; Chiu, W.C.K. Transformational leadership and job performance: A social identity perspective. J. Bus. Res. 2014, 67, 2827-2835. [CrossRef]

78. Jyoti, J.; Bhau, S. Impact of transformational leadership on job performance: Mediating role of leader-member exchange and relational identification. SAGE Open 2015, 5, 2158244015612518. Available online: https://journals.sagepub.com/doi/full/10.117 $7 / 2158244015612518$ (accessed on 2 June 2021). [CrossRef]

79. Bakker, A.B.; van Emmerik, H.; Euwema, M.C. Crossover of burnout and engagement in work teams. Work Occup. 2006, 33, 464-489. [CrossRef]

80. Javed, B.; Abdullah, I.; Zaffar, M.A.; ul Haque, A.; Rubab, U. Inclusive leadership and innovative work behavior: The role of psychological empowerment. J. Manag. Organ. 2019, 25, 554-571. [CrossRef]

81. Javed, B.; Khan, A.K.; Arjoon, S.; Mashkoor, M.; ul Haque, A. Openness to experience, ethical leadership, and innovative work behavior. J. Creat. Behav. 2020, 54, 211-223. [CrossRef]

82. Joniaková, Z.; Jankelová, N.; Blštáková, J.; Némethová, I. Cognitive diversity as the quality of leadership in crisis: Team performance in health service during the COVID-19 pandemic. Healthcare 2021, 9, 313. [CrossRef] [PubMed]

83. Jankelová, N.; Joniaková, Z.; Blštáková, J.; Skorková, Z.; Procházková, K. Leading employees through the crises: Key competences of crises management in healthcare facilities in coronavirus pandemic. Risk Manag. Healthc. Policy 2021, 14, 561-573. [CrossRef] [PubMed]

84. Chen, S.-C.; Chen, C.-F. Antecedents and consequences of nurses' burnout: Leadership effectiveness and emotional intelligence as moderators. Manag. Decis. 2018, 56, 777-792. [CrossRef]

85. Lee, K.-E. Moderating effects of leader-member exchange (LMX) on job burnout in dietitians and chefs of institutional foodservice. Nutr. Res. Pract. 2011, 5, 80-87. [CrossRef]

86. Wu, H.; Qiu, S.; Dooley, L.M.; Ma, C. The relationship between challenge and hindrance stressors and emotional exhaustion: The moderating role of perceived servant leadership. Int. J. Environ. Res. Public. Health 2020, 17, 282. [CrossRef]

87. Zhang, Y.; LePine, J.A.; Buckman, B.R.; Wei, F. It's not fair ... or is it? The role of justice and leadership in explaining work stressor-job performance relationships. Acad. Manag. J. 2014, 57, 675-697. [CrossRef]

88. Cavanaugh, M.A.; Boswell, W.R.; Roehling, M.V.; Boudreau, J.W. An empirical examination of self-reported work stress among U.S. managers. J. Appl. Psychol. 2000, 85, 65-74. [CrossRef] [PubMed]

89. Russell, L.M. An empirical investigation of high-risk occupations: Leader influence on employee stress and burnout among police. Manag. Res. Rev. 2014, 37, 367-384. [CrossRef]

90. Syrek, C.J.; Apostel, E.; Antoni, C.H. Stress in highly demanding IT jobs: Transformational leadership moderates the impact of time pressure on exhaustion and work-life balance. J. Occup. Health Psychol. 2013, 18, 252-261. [CrossRef] [PubMed]

91. Ahern, S.; Loh, E. Leadership during the COVID-19 pandemic: Building and sustaining trust in times of uncertainty. BMJ Lead. 2020. Available online: https:// bmjleader.bmj.com/content/leader/early/2020/09/29/leader-2020-000271.full.pdf (accessed on 5 September 2021). [CrossRef]

92. Anderson, L. Leadership during crisis. Lead. Lead. 2018, 2018, 49-54. [CrossRef]

93. Pejtersen, J.H.; Kristensen, T.S.; Borg, V.; Bjorner, J.B. The second version of the Copenhagen psychosocial questionnaire. Scand. J. Public Health 2010, 38, 8-24. [CrossRef]

94. Baka, Ł. Kopenhaski Kwestionariusz Psychospołeczny (COPSOQ II): Podręcznik do Polskiej Wersji Narzẹdzia [Copenhagen Psychosocial Questionnaire (COPSOQ II). A Manual for the Polish Version of the Tool]; CIOP_PIB: Warszawa, Poland, 2019.

95. Baka, Ł.; Basińska, B.A. Psychometryczne właściwości polskiej wersji Oldenburskiego Kwestionariusza Wypalenia Zawodowego (OLBI) [Psychometric properties of the Polish version of the Oldenburg Burnout Inventory (OLBI)]. Med. Pr. 2016, 67, $29-41$. [CrossRef]

96. Tabachnick, B.G.; Fidell, L.S. Using Multivariate Statistics; Pearson Education: Boston, MA, USA, 2013.

97. Hayes, A.F. Introduction to Mediation, Moderation, and Conditional Process Analysis: A Regression-Based Approach, 2nd ed.; Methodology in the Social Sciences; Guilford Press: New York, NY, USA, 2018.

98. Hayes, A.F. PROCESS: A Versatile Computational Tool for Observed Variable Mediation, Mod-Eration, and Conditional Process Modeling (White Paper). Available online: http:/ / www.afhayes.com/index.html (accessed on 28 July 2021).

99. Lepine, J.A.; Podsakoff, N.P.; Lepine, M.A. A meta-analytic test of the challenge stressor-hindrance stressor framework: An explanation for inconsistent relationships among stressors and performance. Acad. Manag. J.J. Vocat. Behav. 2005, 48, 764-775. [CrossRef]

100. Bakker, A.B.; Sanz-Vergel, A.I. Weekly work engagement and flourishing: The role of hindrance and challenge job demands. J. Vocat. Behav. 2013, 83, 397-409. [CrossRef]

101. Fillion, L.; Tremblay, I.; Truchon, M.; Côté, D.; Struthers, C.W.; Dupuis, R. Job satisfaction and emotional distress among nurses providing palliative care: Empirical evidence for an integrative occupational stress-model. Int. J. Stress Manag. 2007, 14, 1-25. [CrossRef] 
102. Rutter, D.R.; Fielding, P.J. Sources of occupational stress: An examination of British prison officers. Work Stress 1988, 2, $291-299$. [CrossRef]

103. Newmeyer, M.; Keyes, B.; Gregory, S.; Palmer, K.; Buford, D.; Mondt, P.; Okai, B. The Mother Teresa effect: The modulation of spirituality in using the CISM model with mental health service providers. Int. J. Emerg. Ment. Health 2014, 16, 251-258. [CrossRef]

104. McCabe, R.; Nowak, M.; Mullen, S. Nursing careers: What motivated nurses to choose their profession? Aust. Bull. Labour 2005, 31, 384-406.

105. McQueen, A.C.H. Emotional intelligence in nursing work. J. Adv. Nurs. 2004, 47, 101-108. [CrossRef]

106. Bolton, S. Changing faces: Nurses as emotional jugglers. Sociol. Health Illn. 2001, 23, 85-100. [CrossRef]

107. Chua, R.Y.J.; Ingram, P.; Morris, M.W. From the head and the heart: Locating cognition- and affect-based trust in managers' professional networks. Acad. Manag. J. 2008, 51, 436-452. [CrossRef]

108. Connelly, B.L.; Crook, T.R.; Combs, J.G.; Ketchen, D.J.; Aguinis, H. Competence- and integrity-based trust in interorganizational relationships: Which matters more? J. Manag. 2018, 44, 919-945. [CrossRef]

109. Lui, S.S.; Ngo, H. The role of trust and contractual safeguards on cooperation in non-equity alliances. J. Manag. 2004, 30, 471-485. [CrossRef]

110. Sitkin, S.B.; Roth, N.L. Explaining the limited effectiveness of legalistic "remedies" for trust/distrust. Organ. Sci. 1993, 4, 367-392. [CrossRef]

111. Gausdal, A.H.; Makarova, J. Trust and safety onboard. WMU J. Marit. Aff. 2017, 2, 197-217. [CrossRef]

112. Bass, B.I.; Cigularov, K.P.; Chen, P.Y.; Henry, K.L.; Tomazic, R.G.; Li, Y. The effects of student violence against school employees on employee burnout and work engagement: The roles of perceived school unsafety and transformational leadership. Int. J. Stress Manag. 2016, 23, 318-336. [CrossRef]

113. Rugulies, R.; Sørensen, J.K.; Madsen, I.E.H.; Nordentoft, M.; Sørensen, K.; Framke, E. Can leadership quality buffer the association between emotionally demanding work and risk of long-term sickness absence? Eur. J. Public Health 2021. [CrossRef]

114. Madsen, I.E.H.; Hanson, L.L.M.; Rugulies, R.; Theorell, T.; Burr, H.; Diderichsen, F.; Westerlund, H. Does good leadership buffer effects of high emotional demands at work on risk of antidepressant treatment? A prospective study from two Nordic countries. Soc. Psychiatry Psychiatr. Epidemiol. 2014, 49, 1209-1218. [CrossRef] [PubMed]

115. Engel, S.; Wörfel, F.; Maria, A.S.; Wolter, C.; Kleiber, D.; Renneberg, B. Leadership climate prevents emotional exhaustion in German police officers. Int. J. Police Sci. Manag. 2018, 20, 217-224. [CrossRef] 